\title{
demandia
}

ISSN 2477-6106 | E-ISSN 2502-2431 | http://bit.do/demandia

\section{ANALISIS KOMPONEN VISUAL DASAR SINEMATOGRAFI DALAM FILM LIVE ACTION “GREEN BOOK”}

\author{
Puri Sulistiyawati ${ }^{1}$, Dimas Irawan Ihya' Ulumuddin ${ }^{2}$ \\ 1,2Desain Komunikasi Visual, Fakultas IImu Komputer \\ Universitas Dian Nuswantoro, Jl. Imam Bonjol 207 Semarang, Semarang 50131 \\ Email: puri.sulistiya@gmail.com,dimas.dkv@gmail.com
}

Received: 20 Agustus 19

Revised: 11 September 2019

Accepted: 23 September 2019

\begin{abstract}
Abstrak: Sinematografi dapat diartikan dengan ilmu yang mempelajari tentang cara menangkap dan menggabungkan gambar menjadi rangkaian gambar yang bercerita. Film adalah produk sinematografi yang memiliki karakteristik terdiri dari beberapa gambar yang digabungkan. Gambar biasanya terdapat komponen yang mampu menunjukkan arti dari gambar tersebut. Salah satu komponennya yaitu visual. Komponen visual ini dapat ditemukan pada setiap gambar, baik itu gambar bergerak maupun gambar tidak bergerak. Penelitian ini bertujuan untuk menganalisis komponen visual dasar pada film Green Book berdasarkan teori Bruce Block dengan pendekatan deskriptif kualitatif. Komponen visual dasar yang dianalisis meliputi space, line, shape, tone, color, movement, dan rhythm. Film Green Book dipilih karena menjadi film terbaik yang mendapatkan banyak penghargaan salah satunya Best Pictures pada Academy Award 2019. Film Green Book memiliki genre drama komedi-biografi yang menceritakan tentang persahabatan antara Tony Lip dan Don Shirley yang pada dasarnya memiliki sifat yang berbeda. Sesuai dengan teori yang diungkapkan Bruce Block bahwa komponen visual sangat berpengaruh dalam mengkomunikasikan suasana hati dan emosi.
\end{abstract}

Kata kunci komponen visual dasar, sinematografi, film Green Book

\begin{abstract}
Cinematography can be interpreted with the study of how to capture and combine pictures into a series of pictures that tell a story. Film is a cinematographic product that has characteristics consisting of several pictures combined. Pictures usually have components that are able to show the meaning of these pictures. One of the components is visual. This visual component can be found in every picture, either a moving picture or a motion picture. The purpose of this research is to analyze the basic visual components of the Green Book film based on Bruce Block's theory with a qualitative descriptive approach. The basic visual components analyzed consist of space, line, shape, tone, color, movement, and rhythm. The Green Book was chosen because it was the best film rewarded many awards, one of which was Best Pictures at the Academy Award 2019. The Green Book film is a comedy-biography gendre that tells about friendship between Tony Lip and Don Shirley, which basically has different characteristics. According to Bruce Block's theory, the visual component is very influential in communicating moods and emotions.
\end{abstract}

Keywords: basic visual component, cinematography, Green Book film 


\section{PENDAHULUAN}

Sinematografi merupakan bidang ilmu yang mempelajari tentang cara menangkap dan menggabungkan gambar menjadi rangkaian gambar yang bercerita. Sinematografi adalah bahasa yang di dalamnya terdapat kosakata bahasa tentang lensa, komposisi, desain visual pencahayaan, image control, continuity, movement, dan point of view, yang mana "puisi" dapat dibuat dengan bahasa tersebut (Brown, 2012). Sinematografi sebagai ilmu terapan masih memiliki keterkaitan dengan bidang ilmu fotografi. Secara teknik fotografi membahas tentang bagaimana menangkap gambar, sedangkan sinematografi membahas tentang bagaimana menggabungkan rangkaian gambar agar dapat menyampaikan pesan atau informasi. Sinematografi pada dasarnya bukan sekedar pengambilan gambar namun meliputi pembangunan ide, kata-kata, aksi, emosi, tone dan berbagai format komunikasi non-verbal dan meramunya dalam karya visual (Brown, 2012).

Salah satu produk dari sinematografi yaitu film. Film merupakan media hiburan yang sering dijumpai dalam kehidupan masyarakat. Film sebagai media komunikasi audio-visual memiliki pesan untuk disampaikan kepada penikmatnya. Pesan tersebut dapat berupa informasi, edukasi, atau hiburan. Film saat ini diartikan sebagai suatu genre seni bercerita berbasis audio visual, atau cerita yang dituturkan kepada penonton melalui gambar bergerak (Zoebazary, 2010). Film dapat dikategorikan menjadi beberapa jenis yaitu, film dokumenter, film cerita pendek (short films), film cerita panjang (feature-length films), dan film jenis lainnya seperti, profil perusahaan, iklan televisi, program televisi, dan video klip (Effendy, 2009).

Menurut Block (2008, pp2-3), gambar hampir selalu ditemui di dalam kehidupan, baik itu gambar statis seperti buku dan majalah, maupun gambar dinamis yang berupa film dan video. Pada intinya semua itu hanyalah sebuah gambar. Setiap gambar terdiri dari sebuah cerita, visual, dan suara. Setiap 
gambar dapat dipecah menjadi tiga elemen dasar seperti, cerita, suara, dan visual. Elemen dasar dari visual sendiri yaitu komponen visual dasar. Komponen visual ini dapat ditemukan pada setiap gambar baik yang bergerak maupun yang tidak bergerak. Film pada dasarnya merupakan rangkaian gambar yang bergerak dan tentunya memiliki komponen visual dasar. Bagian dari film seperti aktor, lokasi, properti, kostum, dan pemandangan menjadi bentuk dari komponen visual. Fungsi dari komponen visual tersebut adalah mengkomunikasikan suasana hati, emosi, ide, serta memberikan struktur visual pada film.

Greenbook merupakan sebuah film dengan genre drama komedi-biografi yang diproduksi pada tahun 2018 arahan dari sutradara Peter Farrelly. Film tersebut berlatar tahun 1962 terinspirasi berdasarkan kejadian nyata dari sebuah tur musik Deep South yang dilakukan oleh pianis klasik dan jazz keturunan AfrikaAmerika yang bernama Don Shirley bersama seorang supir dan bodyguard-nya yaitu Tony "Lip" Vallelonga. Menceritakan tentang perjalanan Don Shirley bersama dengan Tony dalam mengunjungi tempat-tempat digelarnya konser musik Don Shirley. Menariknya banyak kejadian tidak terduga yang dialami oleh keduanya. Greenbook menjadi film yang banyak mendapatkan review positif dari para kritikus dan penghargaan. Dalam Toronto International Film Festival 2018, film tersebut memenangkan People's Choice Award. Selain itu, penghargaan paling bergengsi adalah menjadi pemenang dalam perhelatan $91^{\text {st }}$ Academy Awards dengan kategori Best Picture.

Berdasarkan uraian di atas, peneliti ingin menganalisis bagaimana komponen visual dasar yang ada dalam film Greenbook. Analisis pada film sudah pernah dilakukan sebelumnya seperti yang dilakukan oleh Essa Karina yang menganalisis tentang teknik sinematografi pada film Paranormal Activity. Analisis yang dilakukan mengenai penerapan teknik sinematografi meliputi arah gambar, ukuran shot, dan pergerakan gambar (Karina, 2016). Penelitian lain yaitu analisis sinematografi pada film Polem Ibrahim dan Dilarang Mati di Tanah Sendiri. 
Analisis dilakukan dengan mencari unsur-unsur sinematografi seperti komposisi, frame, lighting, angle, dan warna untuk mencari perbedaan diantara kedua film tersebut (Yuwandi, 2018). Green Book sebagai film yang mendapatkan banyak reaksi positif dan menjadi film terbaik dalam 91 ${ }^{\text {st }}$ Academy Award tentu secara fundamental haruslah memiliki komponen visual yang menarik. Sesuai dengan teori yang diungkapkan Bruce Block bahwa basic component visual atau komponen visual dasar sangat berpengaruh dalam mengkomunikasikan suasana hati dan emosi. Hasil analisis komponen visual dasar tersebut meliputi space (ruang), line (garis), shape (bentuk), tone (kecerahan), color (warna), movement (pergerakan), dan rhythm (ritme).

\section{METODE PENELITIAN}

Penilitian ini dilakukan dengan menggunakan metode deskriptif kualitatif, dimana metode tersebut memiliki ciri yang berusaha mengkonstruksi realitas serta memahami maknanya (Somantri, 2005). Metode deskriptif kualitatif ini digunakan untuk mendapatkan informasi dan membuat deskripsi yang mendalam tentang pengamatan terhadap film Green Book. Tahap pertama dilakukan dengan mengamati tiap scene yang ada pada film Green Book. Kemudian pengumpulan data dilakukan dengan studi pustaka dan dokumentasi dengan mencari berbagai referensi berupa buku atau jurnal.

Analisis pada film Green Book dilakukan dengan pendekatan basic component visual yang membedah tujuh aspek yaitu, space, line, shape, tone, color, movement, dan rhytm. Analisis dilakukan dengan mengamati film yang berbasis audio-visual yang memiliki durasi 2 jam 10 menit. Setelah dilakukan pengamatan, tahap berikutnya adalah melakukan identifikasi terhadap tujuh komponen visual dasar. Komponen-komponen tersebut kemudian ditinjau dan dikaitkan dengan tiap scene yang ada pada film Green Book. 


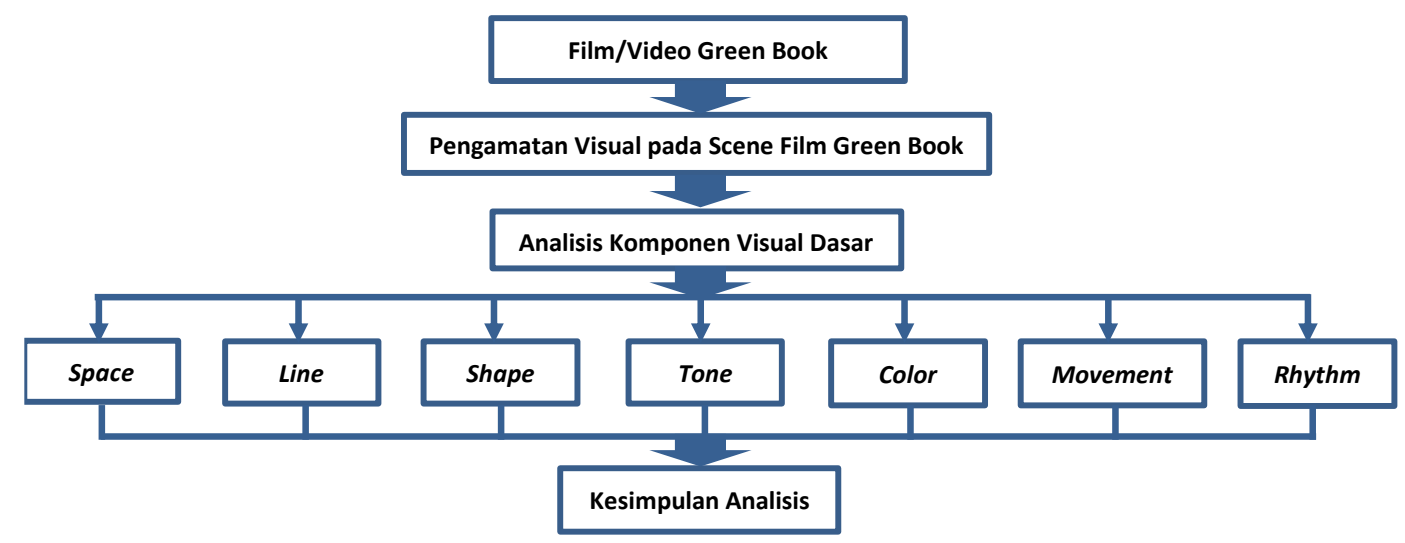

Gambar 1 Bagan Proses Analisis Film Green Book

Sumber: Sulistiyawati dan Ulumuddin, 2019

\section{HASIL DAN DISKUSI}

\section{Sinopsis film Green Book}

Greenbook merupakan film tentang biografi komedi-drama yang diarahkan oleh Peter Farrelly dan diproduksi tahun 2018. Film ini diangkat dari kisah nyata dari mantan seorang penjaga klub malam, Tony "Lip" Vallelonga. Tony kemudian bertemu dengan pianis jazz kelas dunia yang berkulit hitam, Dr. Don Shirley yang kemudian menjadikan Tony sebagai sopir sekaligus bodyguardnya selama tur konser musik dari Manhattan ke Deep South. Judul Green Book sendiri sebenarnya mengarah pada buku panduan yang berwarna hijau bagi para pelancong kulit hitam yang melakukan perjalanan ke daerah-daerah yang penuh dengan diskriminatif. Film ini lebih fokus pada cerita dramatisasi persahabatan antara Tony dan Don Shirley. Menyajikan kisah yang berbeda yang biasanya orang kulit hitam sebagai bawahan dan orang kulit putih sebagai atasan, dalam film ini semua serba terbalik. Isu rasial yang sangat tinggi akan memberikan gambaran rasisme di Amerika pada tahun 60-an. Persahabatan antara Tony dan Don Shirley sangat tampak nyata, saling membantu, berbagi canda tawa, hingga konflik keduanya begitu sangat baik dibalut dengan komedi cerdas. 


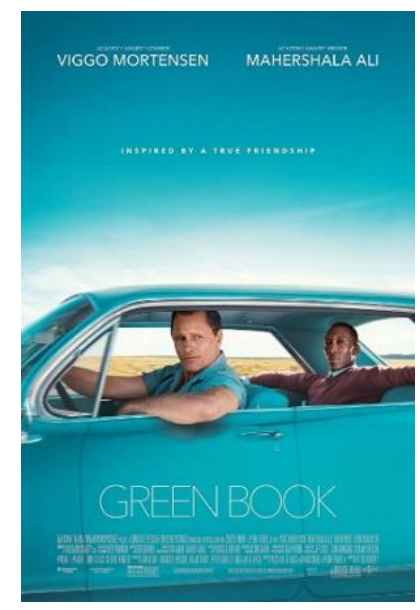

Gambar 2 Poster film Green Book

Sumber: https://www.imdb.com/

Selain itu, secara visual film Green Book dikemas dengan sangat rapih. Penggunaan tone warna dan pengalaman sinematiknya menyajikan gambaran visual yang benar-benar indah. Ditambah chemistry antara Viggo dan Mahershala sangat kompak dan begitu hangat. Film ini banyak mendapatkan penghargaan mulai dari "Best Pictures" dalam ajang Producers Guild Awards (PGA) 2019, memenangkan sederet nominasi dalam Golden Globe 2019, Best Pictures dalam Academy Award 2019, selain itu juga memenangkan Best Original Screenplay dan pemeran Don Shirley, Mahershala Ali mendapatkan penghargaan Best Supporting Actor.

\section{Analisis Basic Component Visual}

\section{Space}

Space dalam dunia nyata merupakan ruang 3 dimensi yang terdiri dari lebar, tinggi, dan kedalaman. Layar dalam film, televisi, dan komputer merupakan permukaan yang rata, tidak dapat diukur dari lebar dan tinggi, bahkan tidak memiliki kedalaman. Meskipun layar memiliki bentuk 2 dimensi 
tetapi gambar dalam film dianggap sebagai representasi realistis dari dunia nyata. Sub-komponen space terdiri dari deep space, flat space, limited space, dan ambiguous space.

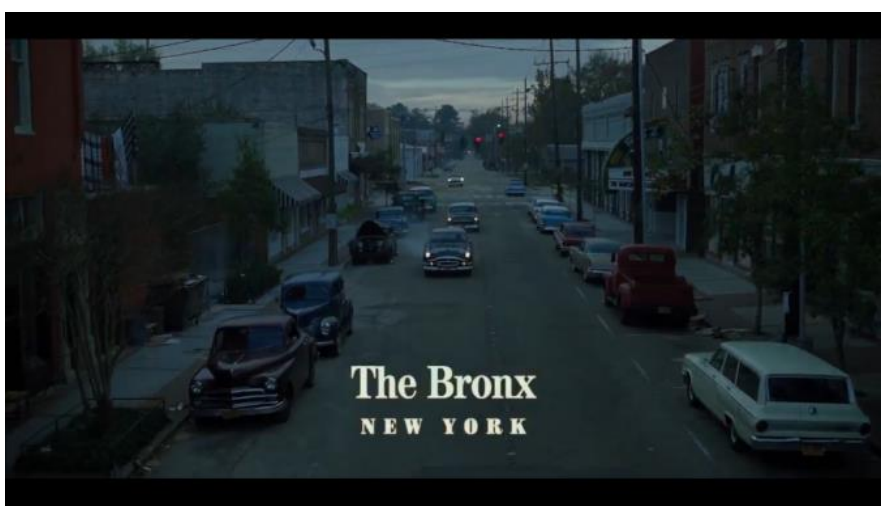

Gambar 3 Scene ketika Tony Lip pulang menggunakan mobil Sumber: Screenshoot film Green Book

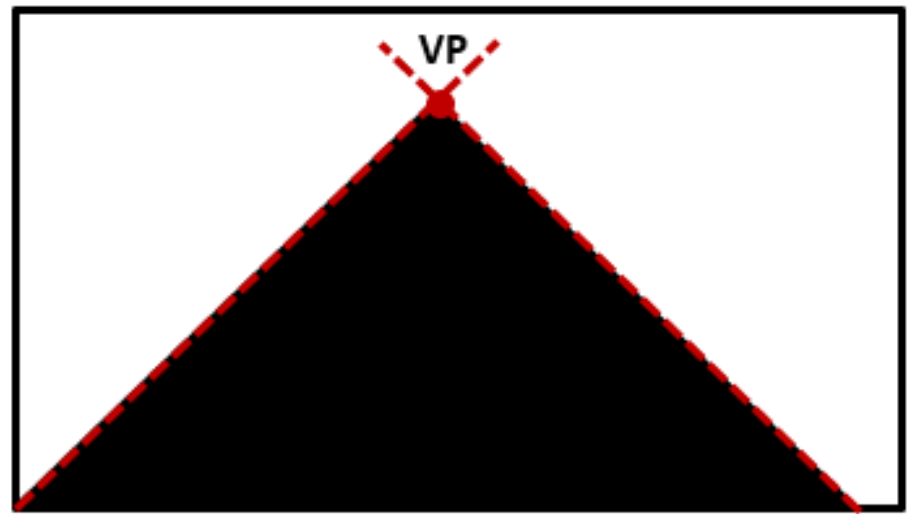

Gambar 4 Visualisasi vanishing point pada satu bidang Sumber: Sulistiyawati dan Ulumuddin, 2019

Adegan tersebut menggambarkan Tony Lip yang sedang pulang ke rumahnya dengan mengendarai mobil. Secara visual, scene ini menunjukkan adanya deep space yang terlihat dari detail objek mobil yang menunjukkan perubahan ukuran dari kecil menjadi besar. Objek jalan dalam scene tersebut 
menunjukan adanya bidang yang di sepanjang bagian kanan dan kiri terdapat garis. Garis-garis tersebut tampak bertemu satu sama lain pada satu titik yang disebut vanishing point (titik hilang).

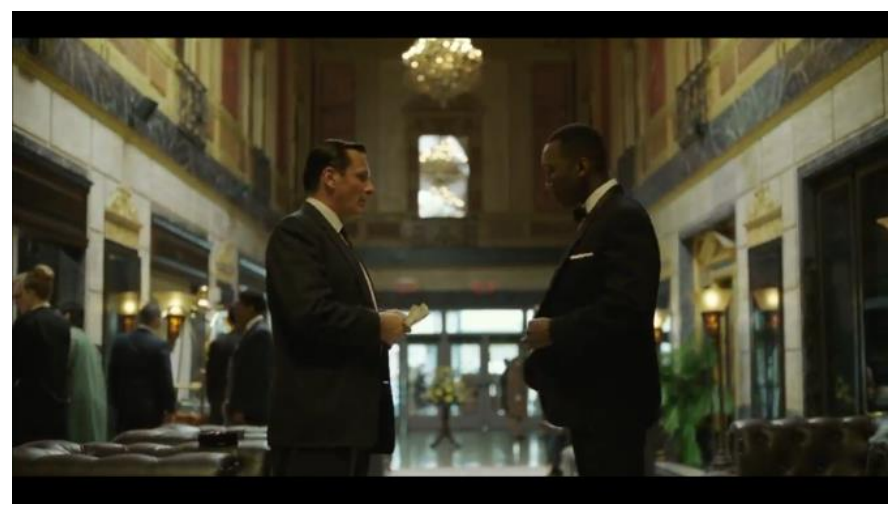

Gambar 5 Scene Tony Lip dan Don Shirley di hotel Sumber: Screenshoot film Green Book

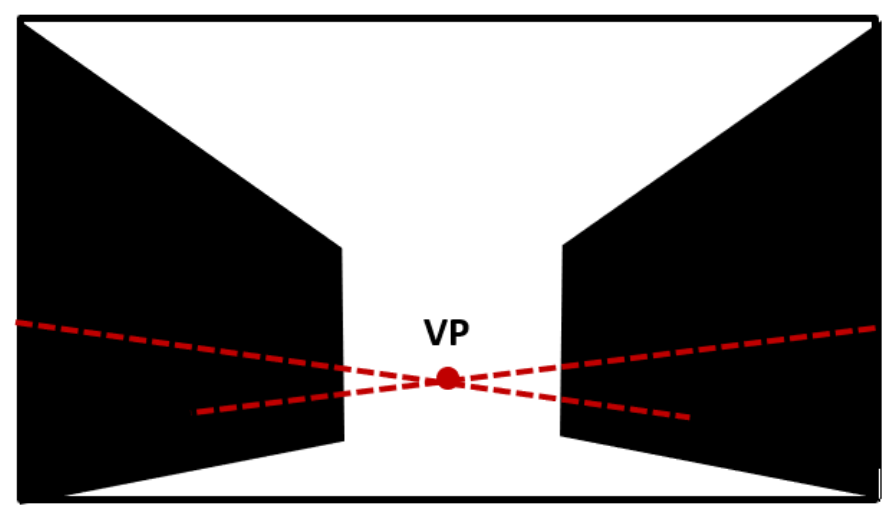

Gambar 6 Visualisasi vanishing point pada dua bidang Sumber: Sulistiyawati dan Ulumuddin, 2019

Adegan tersebut menceritakan saat Tony Lip dan Don Shirley sedang berdiskusi di lobi hotel. Pada scene ini (Gambar 5), terlihat dua sisi dinding yang membentuk bidang bagian kanan dan kiri. Jika ditengah-tengah kedua bidang tersebut ditarik garis, maka akan ada dua garis yang akan saling bertemu pada 
satu titik. Titik tersebut juga disebut sebagai vanishing point (titik hilang). Scene tersebut menunjukkan adanya deep space, meskipun layar hanya tampak dalam 2 dimensi tetapi dalam adegan tersebut 3 dimensi ditunjukkan dengan adanya vanishing point, sehingga pada kedua scene tersebut representasi visual sebenarnya memiliki kedalaman ruang.

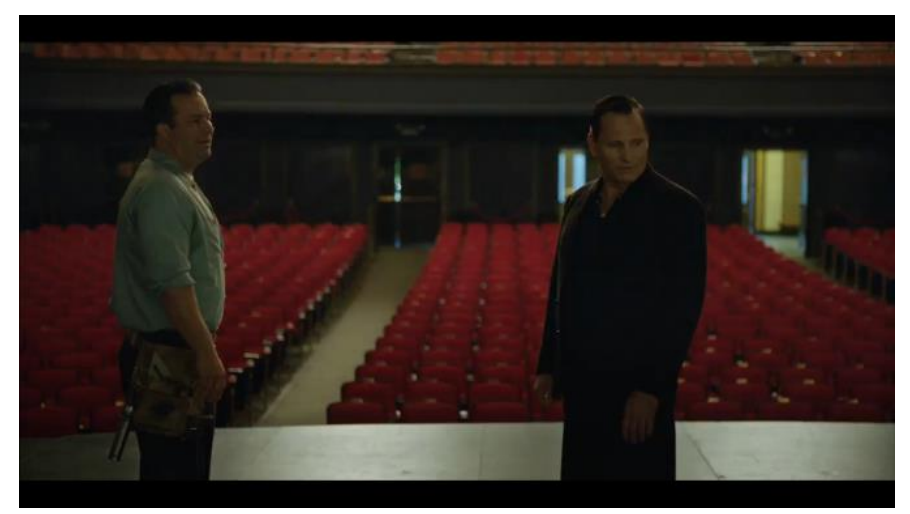

Gambar 7 Scene Tony Lip sedang berseteru dengan pengurus konser Sumber: Screenshoot film Green Book

Scene pada Gambar 7 menggambarkan bagaimana Tony Lip sedang berseteru dengan pengurus konser mengenai alat musik piano yang disediakan tidak sesuai dengan permintaan Don Sirley. Scene ini menunjukkan komponen visual flat space, yang mana terlihat bidang yang frontal, bukan longitudinal. Bidang frontal menekankan pada 2 dimensi dari permukaan layar. Hal tersebut ditunjukkan juga dengan adanya dua aktor yang memiliki kesamaan ukuran dan posisi. 


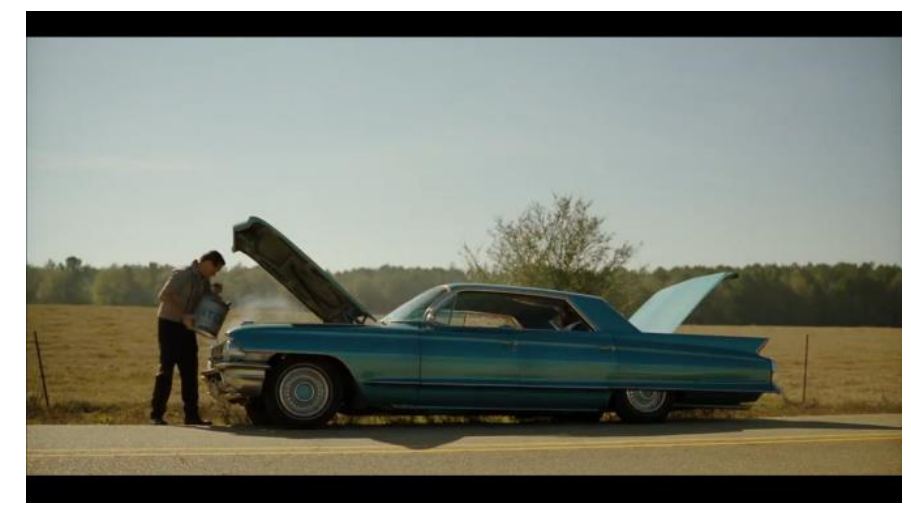

Gambar 8 Scene Tony Lip memperbaiki mobil yang mogok

Sumber: Screenshoot film Green Book

Scene pada Gambar 8 tersebut memiliki komponen visual yang sama yaitu flat space. Pada adegan tersebut Tony Lip sedang mengisi air kompresor pada mesin mobil yang sedang mogok. Tony Lip digambarkan sedang berdiri di tepi jalan dan di belakangnya terdapat padang rumput yang luas. Tidak ada garis longitudinal yang memperlihatkan visual 3 dimensi. Semua elaman visual membentuk bidang frontal yang menjelaskan bahwa hanya terdapat visual 2 dimensi.

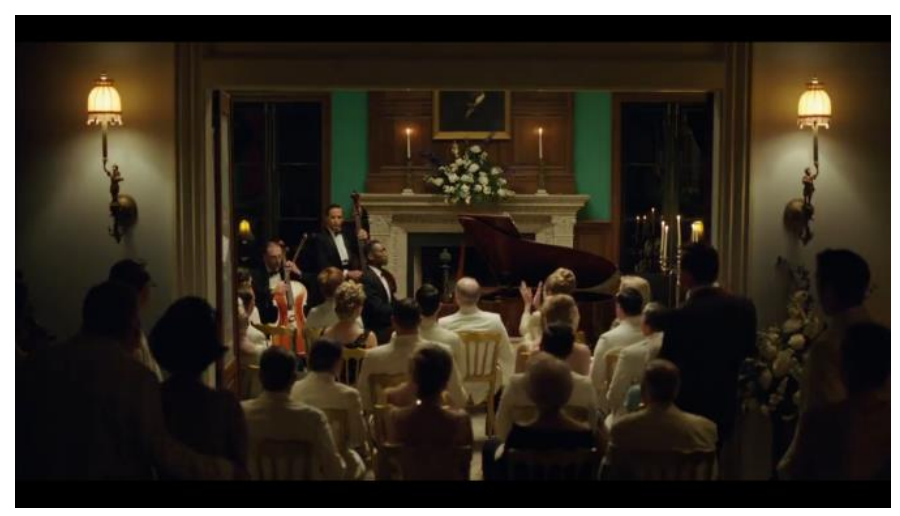

Gambar 9 Scene Don Shirley dan band sedang konser Sumber: Screenshoot film Green Book

Adegan pada Gambar 9 tersebut menceritakan ketika Don Shirley dan band sedang melakukan konser di sebuah tempat yang cukup kecil. Dalam scene 
tersebut tampak para penonton yang berada pada ruangan yang dipisah dinding ditengah ruangan. Scene tersebut menunjukkan adanya sub-komponen space yaitu limited space. Limited space merupakan kombinasi khusus dari deep dan flat space. Menunjukkan adanya kedalaman namun juga menunjukkan bidang yang frontal. Kedalaman pada limited space tidak digunakan karena bidang longitudinal yang biasanya dikaitkan dengan deep space telah diganti dengan bidang frontal.

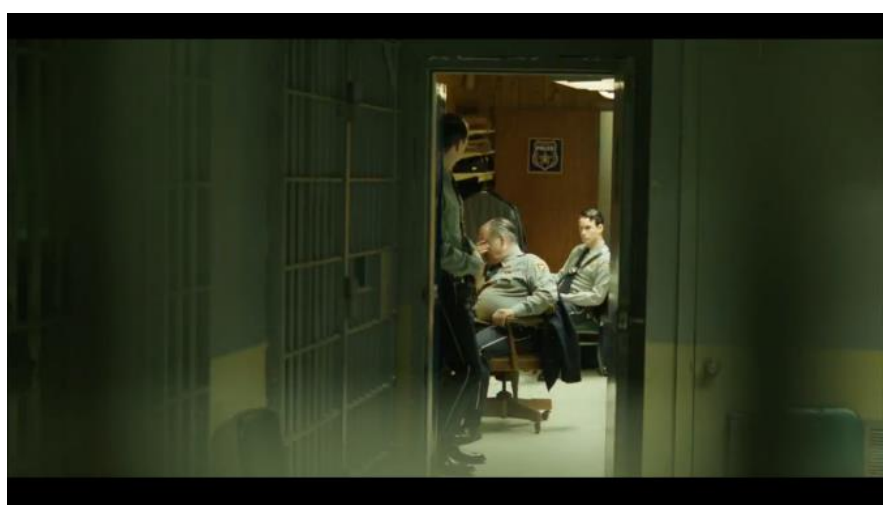

Gambar 10 Scene polisi yang sedang menahan Tony Lip dan Don Shirley Sumber: Screenshoot film Green Book

Scene pada Gambar 10 tersebut juga menampilkan komponen visual limited space. Limited space memerlukan pemisah secara fisik maupun visual diantara bidang frontal. Berdasarkan posisi Tony Lip dan Don Shirley, terdapat tanda kedalaman. Kedalaman yang muncul tidak begitu pengaruh karena terdapat bidang pemisah yang berupa dinding.

\section{Line}

Line atau garis dapat ditemukan di mana-mana. Seperti contoh sebuah pintu yang memiliki dua garis vertikal, dan atau bola yang memiliki garis melengkung. Line berbeda dari komponen visual lainnya, karena line hanya muncul karena kontras tonal atau warna. Tergantung pada kontras tersebut, garis bisa saja muncul atau bahkan kabur. 


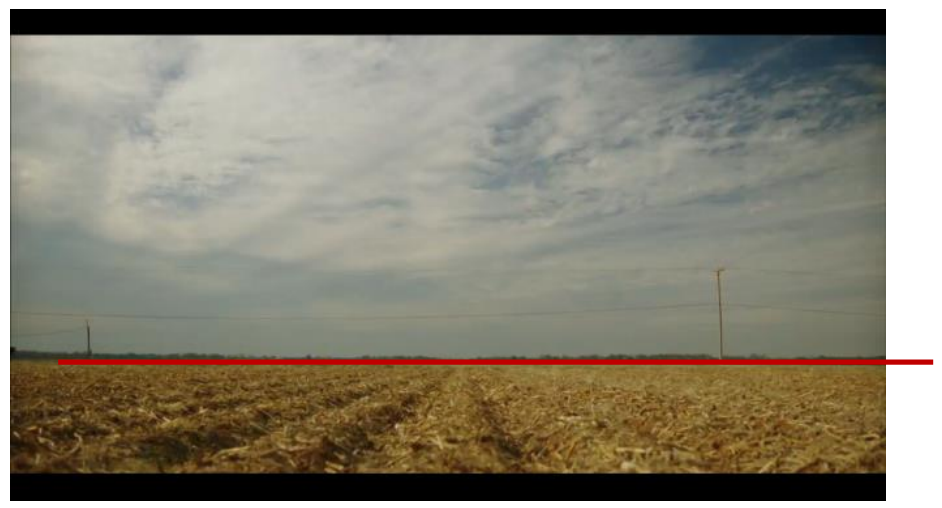

Gambar 11 Scene padang rumput yang luas

Sumber: Screenshoot film Green Book

Scene pada Gambar 11 tersebut menggambarkan sebuah padang rumput yang luas dan terlihat langit yang begitu indah. Pada adegan itu, Tony Lip dan Don Shirley sedang melakukan perjalanan konser ke tempat berikutnya dan melewati tempat tersebut. Line merupakan komponen visual yang muncul pada scene tersebut. Langit dan padang rumput memiliki kontras tonal sehingga diantara keduanya dapat memunculkan garis horizontal. Garis merah merupakan ilustrasi muncul komponen visual line dalam scene tersebut. Line ini dapat disebut sebagai intersection of planes, dimana terdapat dua bidang yang saling bertemu atau bersimpangan, di antara bidang tersebut akan muncul sebuah garis.

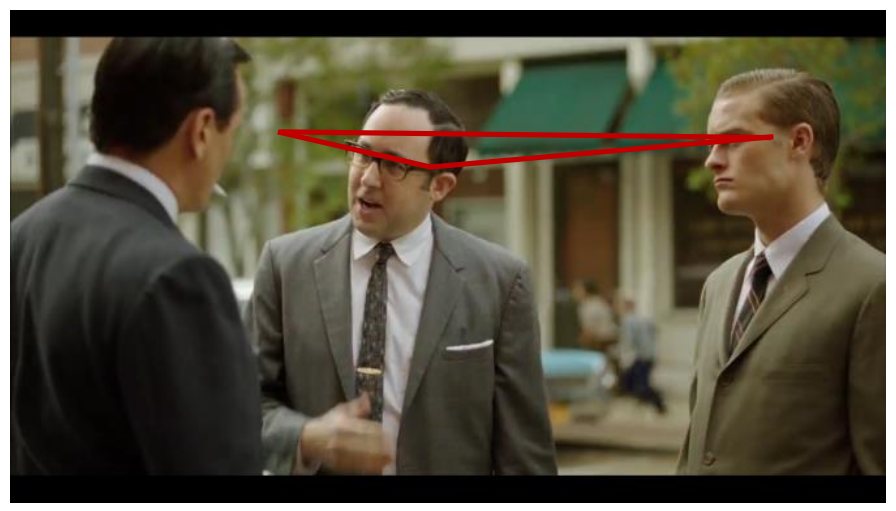

Gambar 12 Scene saat Tony Lip sedang berbicara dengan kedua rekannya Sumber: Screenshoot film Green Book 
Komponen visual yang muncul pada scene di atas (Gambar 12) adalah line. Scene tersebut menggambarkan Tony Lip sedang berbicara dengan kedua rekan kerjanya saat masih di bar. Line yang terbentuk disebut dengan line closure. Ciri-ciri line closure adalah terdapat point of interest utama yang membuat garis imajiner. Scene tersebut menunjukkan adanya tiga tokoh sebagai point of interest. Lalu dari ketiga tokoh tersebut kemudian muncul garis imajiner yang saling berhubungan.

\section{Shape}

Shape merupakan komponen visual yang terdapat pada ruang visual baik itu datar maupun dalam. Shape dapat digolongkan dalam dua kategori yaitu dua dimensi dan tiga dimensi. Contoh dari dua dimensi yaitu lingkaran, kotak, dan segitiga, sedangkan contoh 3 dimensi yaitu bola, kubus, dan piramid. Dalam film Green Book, komponen visual shape yang manonjol adalah basic shape recognition.

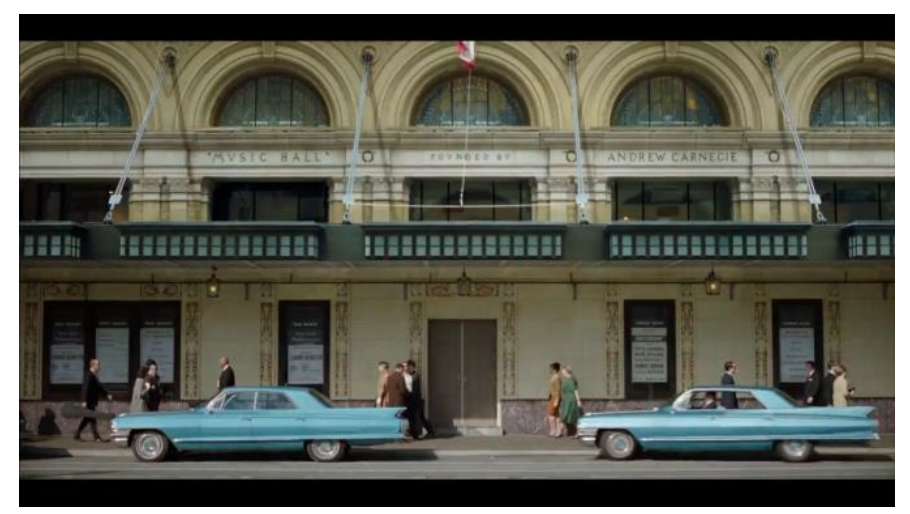

Gambar 13 Scene saat Tony Lip dan Don Shirley serta band bersiap-siap berangkat konser Sumber: Screenshoot film Green Book

Scene pada Gambar 13 tersebut menceritakan pada saat Tony Lip beserta Don Shirley dan band sedang bersiap-siap berangkat menuju tur konser. Secara 
visual terlihat bangunan gedung yang memiliki bentuk-bentuk dasar. Bentuk dasar tersebut yang paling dominan adalah bentuk kotak atau persegi panjang. Bentuk tersebut tampak dari pintu, jendela maupun properti bangunan lainnya. Selain itu muncul juga bentuk dasar seperti setengah lingkaran yang terdapat pada jendela atas bangunan.

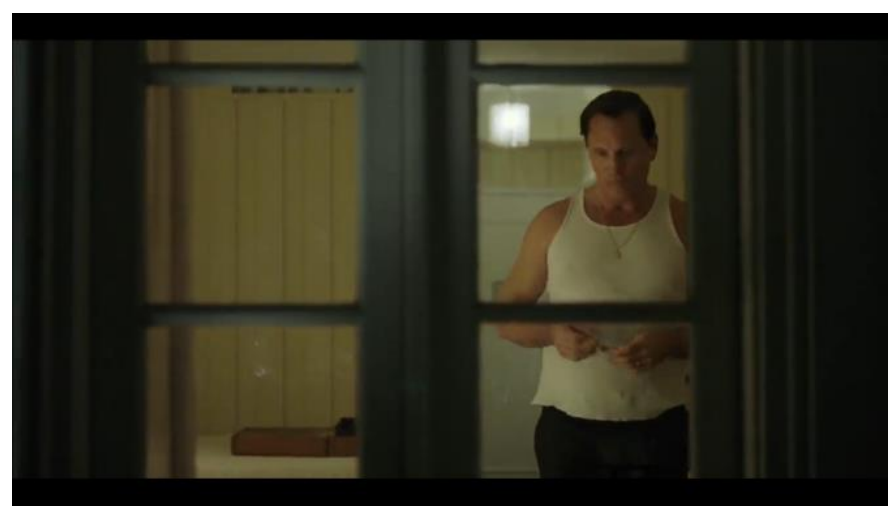

Gambar 14 Scene saat Tony Lip berada di kamar hotel

Sumber: Screenshoot film Green Book

Scene pada Gambar 14 tersebut menceritakan tentang Tony Lip yang sedang beristirahat di kamar hotel setelah mengantar Don Shirley. Sudut pengambilan gambar diambil dari sisi luar jendela kamar hotel yang di dalam terlihat Tony Lip. Shape yang muncul berupa bentuk dasar kotak atau persegi. Bentuk tersebut tampak dari sisi-sisi jendela kaca.

\section{Tone}

Tone merupakan komponen visual dasar yang mudah dijelaskan dan dipahami. Tone dalam hal ini bukan merupakan keras-pelannya suara atau kualitas suara. Tone yang dimaksud di sini adalah kecerahan dari suatu objek. Tone atau tonal dari sebuah gambar dapat membantu menarik perhatian penonton secara langsung. Area yang paling cerah biasanya menarik perhatian penonton lebih dahulu. Jarak tonal sebuah scene juga mempengaruhi suasana hati dan perasaan emosional. 


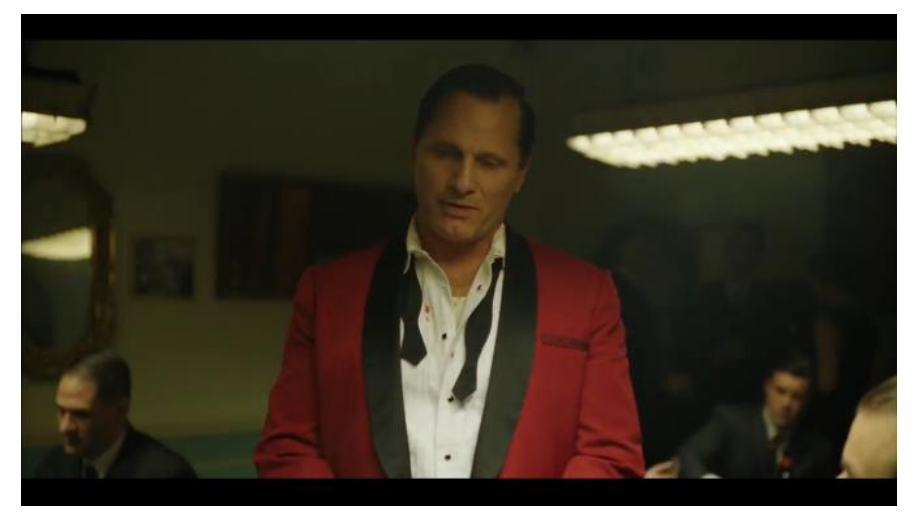

Gambar 15 Scene saat Tony Lip berada di bar dengan Tuan Loscudo Sumber: Screenshoot film Green Book

Scene pada Gambar 15 tersebut menceritakan ketika Tony Lip mengembalikan topi Tuan Loscudo pelanggan di bar milik Tony bekerja. Digambarkan Tony sedang berada di dalam ruangan sebuah bar untuk menemui Tuan Loscudo. Teknik tonal yang digunakan dalam adegan di atas adalah reflective control. Rentang kecerahan gambar dapat dikontrol oleh nilai pantulan aktual objek. Ciri-ciri penggunaan reflective control dalam suatu adegan diantaranya penggunaan cahaya sangat minim bayangan dan cenderung datar. Jumlah cahaya yang terdapat dalam scene tersebut rata-rata memiliki kecerahan yang sama.

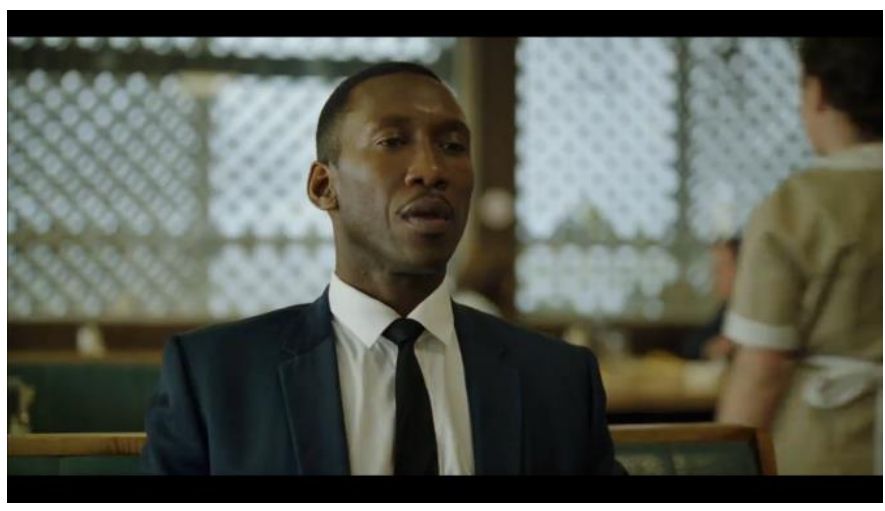

Gambar 16 Scene saat Don Shirley makan siang dengan Tony Lip Sumber: Screenshoot film Green Book 
Scene pada Gambar 16 tersebut menggambarkan Don Shirley yang sedang makan siang di sebuah restoran. Teknik pencahayaan yang digunakan yaitu reflective control, dimana cahaya memiliki intensitas yang sama rata di semua bagian. Tone pada dua scene di atas juga disebut dengan coincidence of tone. coincidence of tone lebih menekankan pada pengorganisasian tonal diantara shot dan subyek. Coincidence of tone terjadi ketika tonal menunjukkan atau mengungkapkan obyek.

\section{Color}

Menurut Bruce Block (Block, 2008), color merupakan komponen yang sulit dideskripsikan karena tidak dapat dijelaskan secara akurat. Dalam kehidupan sehari-hari, warna memberi efek psikologis bagi orang yang melihatnya dan warna juga merupakan bagian terpenting yang dapat menjadi daya Tarik sebuah benda, karya seni, atau desain (Monica, 2011). Penggunaan komponen warna dalam film Green Book memiliki ciri khas tersendiri. Warna yang digunakan cenderung warna yang lembut dan teduh.

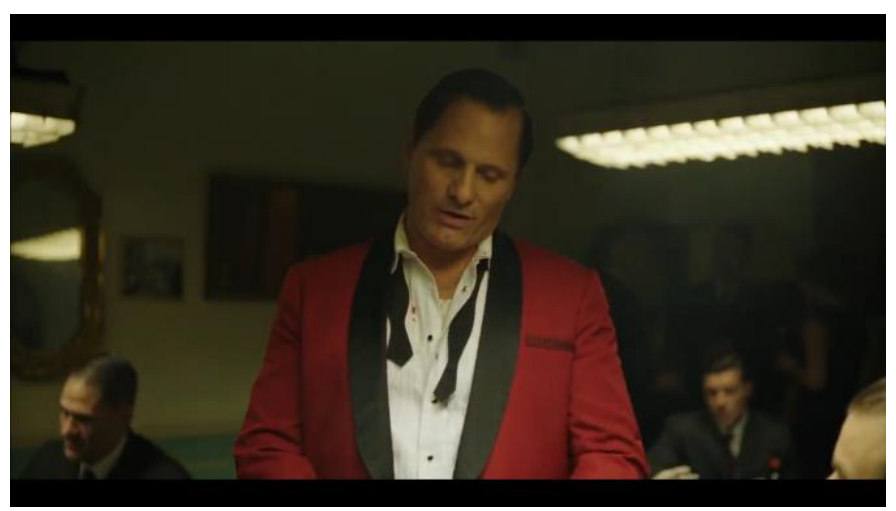

Gambar 17 Scene saat Tony Lip berada di bar dengan Tuan Loscudo Sumber: Screenshoot film Green Book

Penggunaan warna pada scene tersebut (Gambar 17) menunjukkan adanya kontras. Kontras ditunjukkan pada baju yang dipakai oleh Tony Lip yaitu 
merah. Warna merah sangat kontras jika dibandingkan dengan latar belakang yang dipakai pada scene tersebut. Pemilihan warna merah yang kontras juga dapat menunjukkan bahwa seorang Tony Lip yang memiliki peran yang sangat menonjol dalam cerita tersebut.

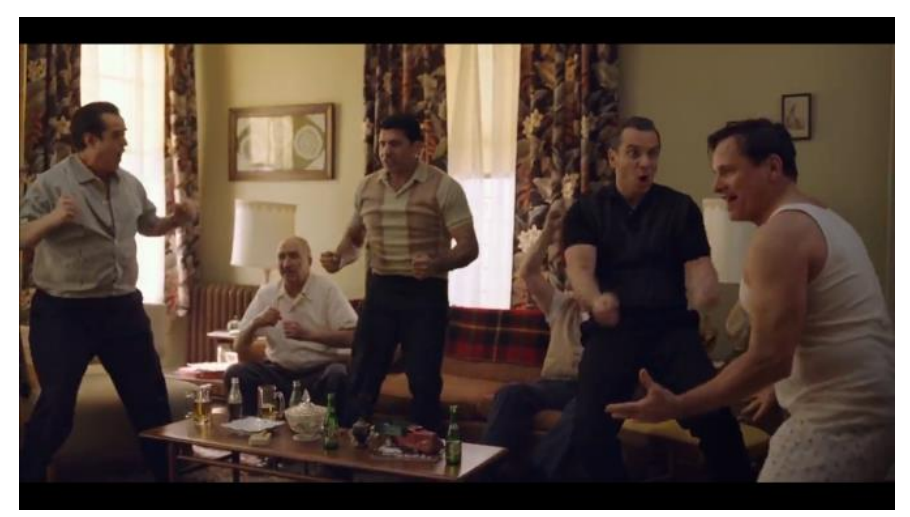

Gambar 18 Scene saat Tony Lip dan keluarganya di rumah Sumber: Screenshoot film Green Book

Contoh scene pada Gambar 18 menggunakan warna yang dominan monokromatik kuning. Warna monokromatik kuning yang dipakai juga terlihat lembut dan teduh. Kuning dapat digunakan untuk memperlihatkan kehangatan keluarga Tony Lip. Hal itu memang menggambarkan karakteristik keluarga Tony yang memiliki kebersamaan yang sangat kuat dan jarang terlibat konflik.

\section{Movement}

Komponen visual movement jika diartikan merupakan sebuah pergerakan. Movement menjadi aspek penting dalam film, karena film itu sendiri mempunyai berbagai adegan yang butuh pergerakan. Pergerakan dapat terjadi pada tiga hal, yaitu pergerakan sebuah obyek, kamera, dan sudut pandang penonton. Film Green Book yang memiliki genre drama yang komponen visual movement di dalamnya cenderung sederhana. Film drama tidak membutuhkan 
banyak pergerakan seperti pada film action yang memiliki pergerakan yang kompleks.

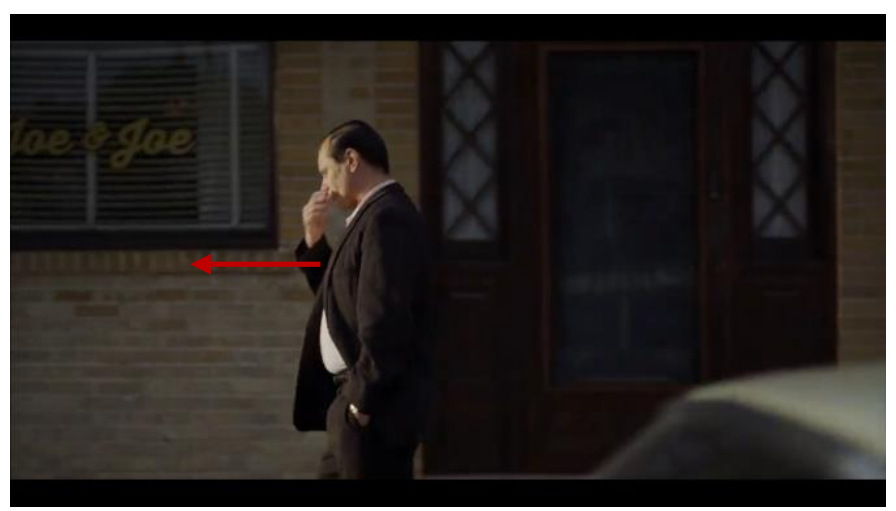

Gambar 19 Scene saat Tony Lip sedang berjalan ke sebuah toko jam

Sumber: Screenshoot film Green Book

Scene pada Gambar 19 tersebut menunjukkan Tony Lip yang sedang berjalan di trotoar menuju ke sebuah bar. Komponen movement dalam adegan tersebut terjadi pada obyek kamera yang menyorot Tony sedang berjalan. Kamera mengikuti Tony hingga sampai ke pintu bar yang dituju. Pergerakan kamera ini dapat disebut dengan tracking shot, yaitu pengambilan sudut gambar yang mengikuti arah pergerakan obyek. Posisi kamera selalu mengikuti obyek sehingga posisinya berubah.

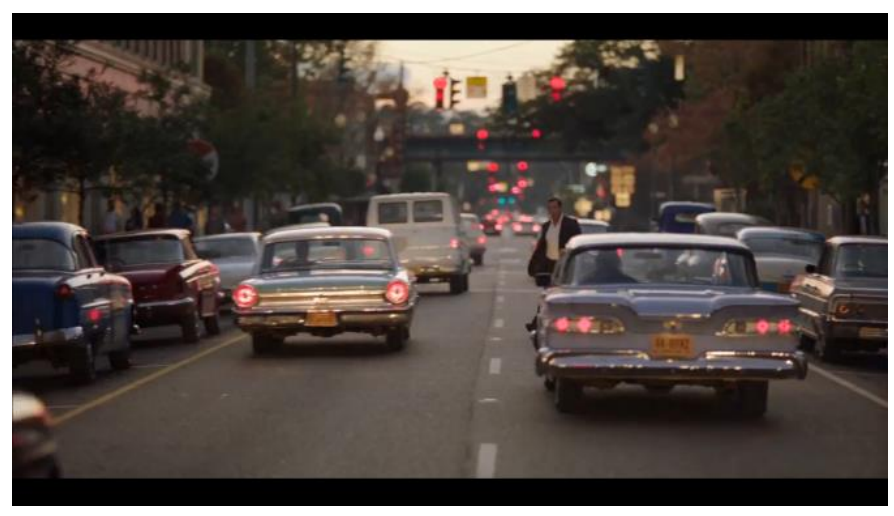

Gambar 20 Scene saat Tony Lip menyebrang jalan Sumber: Screenshoot film Green Book 
Pergerakan yang terjadi pada adegan di atas (Gambar 20) merupakan pergerakan berdasarkan kamera. Adegan tersebut menggambarkan Tony Lip yang sedang menyebrang jalan untuk menuju ke sebuah toko jam. Pergerakan kamera yang terjadi dapat disebut dengan panning. Panning merupakan teknik pengambilan gambar dengan menggerakkan kamera ke kiri atau ke kanan tetapi posisi kamera tetap berada di sumbunya (tidak berubah posisi). Panning dapat diibaratkan seperti kepala yang menoleh ke kiri atau ke kanan.

\section{Rhythm}

Rhythm atau ritme merupakan komponen yang mudah dialami tapi juga sulit dijelaskan. Dalam teorinya Bruce Block, ritme pada film dapat digambarkan melaui apa yang dilihat, apa yang didengar, dan apa yang dirasakan. Dari ketiga hal tersebut yang paling mudah untuk dijelaskan adalah apa yang dilihat. Film Green Book tidak banyak menyajikan ritme yang kompleks. Beberapa adegan masih memiliki ritme untuk menampilkan obyek pada scene tersebut.

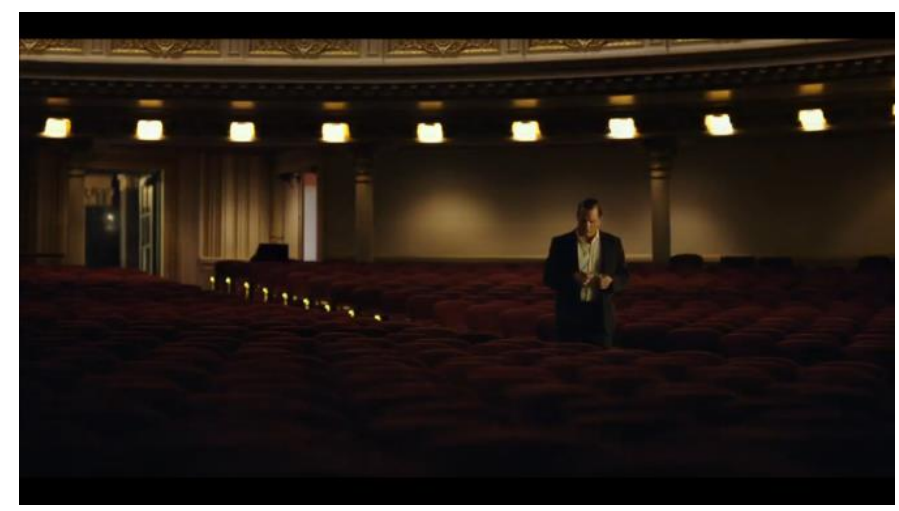

Gambar 21 Scene saat Tony Lip berada di aula konser Sumber: Screenshoot film Green Book

Ritme pada scene (Gambar 21) dapat dijelaskan dari obyek lampu atau obyek kursi. Ritme pada scene tersebut dapat disebut dengan repetition atau perulangan. Obyek lampu maupun kursi tampak memiliki posisi yang berulang- 
ulang. Scene tersebut menggambarkan Tony Lip yang sedang memantau tempat berlangsungnya konser Don Shirley.

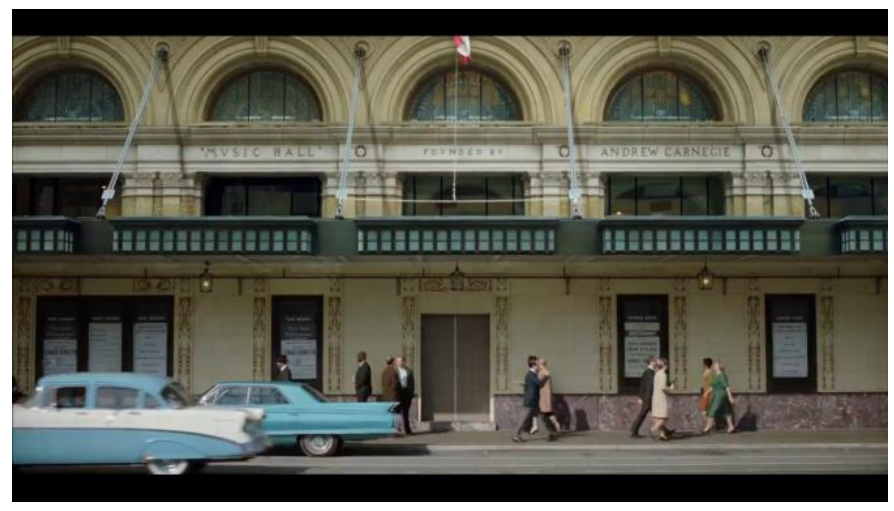

Gambar 22 Scene saat Tony Lip sedang menjemput Don Shirley

Sumber: Screenshoot film Green Book

Ritme juga terdapat pada scene di atas (Gambar 22). Sama seperti scene sebelumnya ritme yang terjadi pada scene tersebut adalah repetition atau perulangan. Repetition atau perulangan terlihat dari obyek jendela baik yang berbentuk setangah lingkaran maupun yang berbentuk persegi.

Kesimpulan hasil analisis dari komponen visual dasar dapat juga dilihat dari tabel berikut ini:

Tabel 1 Hasil analisis komponen visual dasar pada adegan di film Green Book Sumber: Sulistiyawati dan Ulumuddin, 2019

\begin{tabular}{|c|c|c|c|}
\hline No & Scene & Keterangan & $\begin{array}{c}\text { Komponen } \\
\text { Visual } \\
\text { Dasar }\end{array}$ \\
\hline 1 & $\begin{array}{l}\text { le Bron } \\
\text { \& w y }\end{array}$ & $\begin{array}{l}\text { Detail objek mobil } \\
\text { yang menunjukkan } \\
\text { perubahan ukuran } \\
\text { dari kecil menjadi } \\
\text { besar. Objek jalan } \\
\text { dalam scene } \\
\text { tersebut } \\
\text { menunjukan } \\
\text { adanya bidang yang } \\
\text { di sepanjang bagian } \\
\text { kanan dan kiri }\end{array}$ & $\begin{array}{l}\text { Deep } \\
\text { Space }\end{array}$ \\
\hline
\end{tabular}




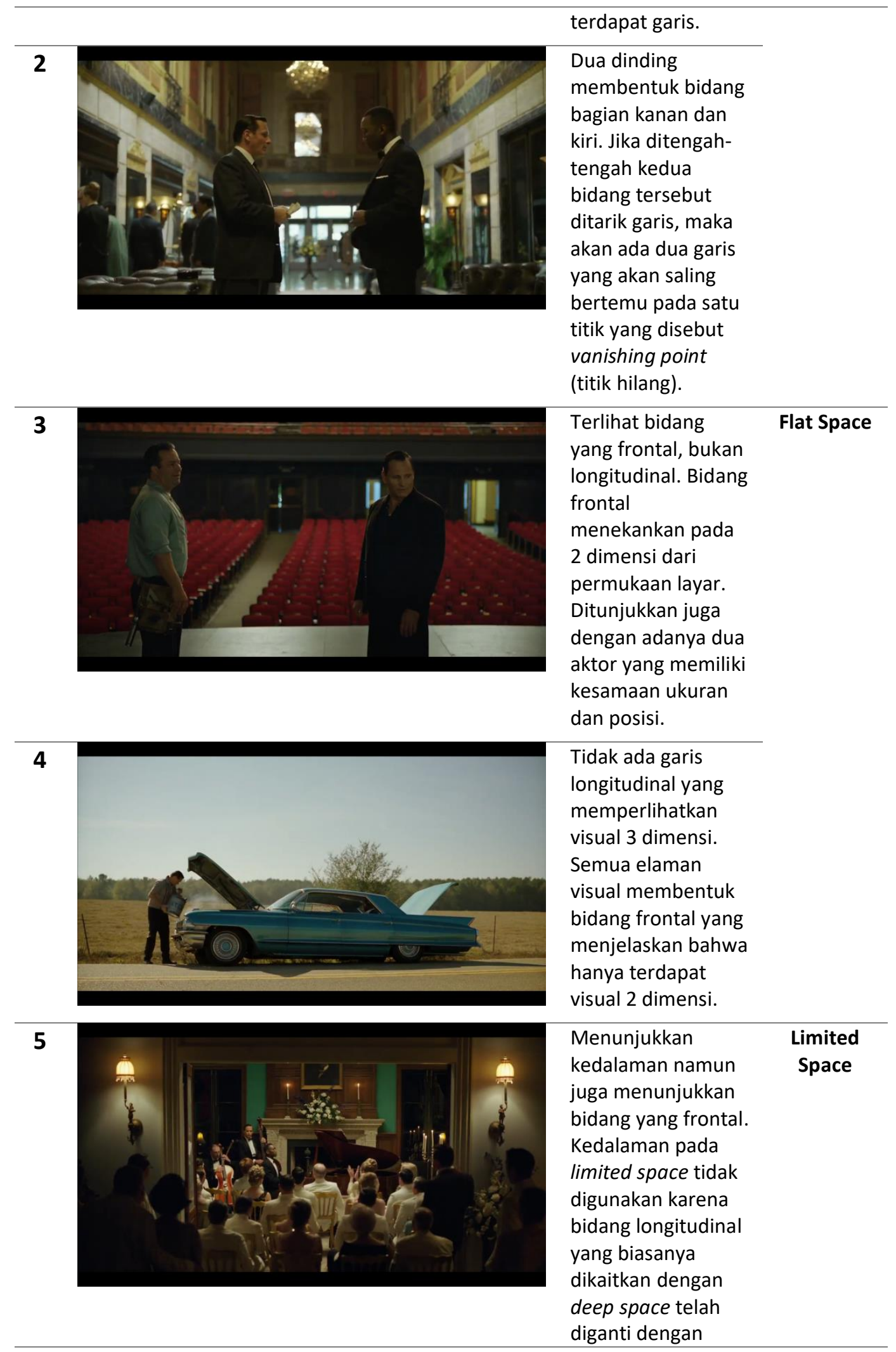


Puri Sulistiyawati dan Dimas Irawan Ihya' Ulumuddin ANALISIS KOMPONEN VISUAL DASAR SINEMATOGRAFI DALAM FILM LIVE ACTION "GREEN BOOK"

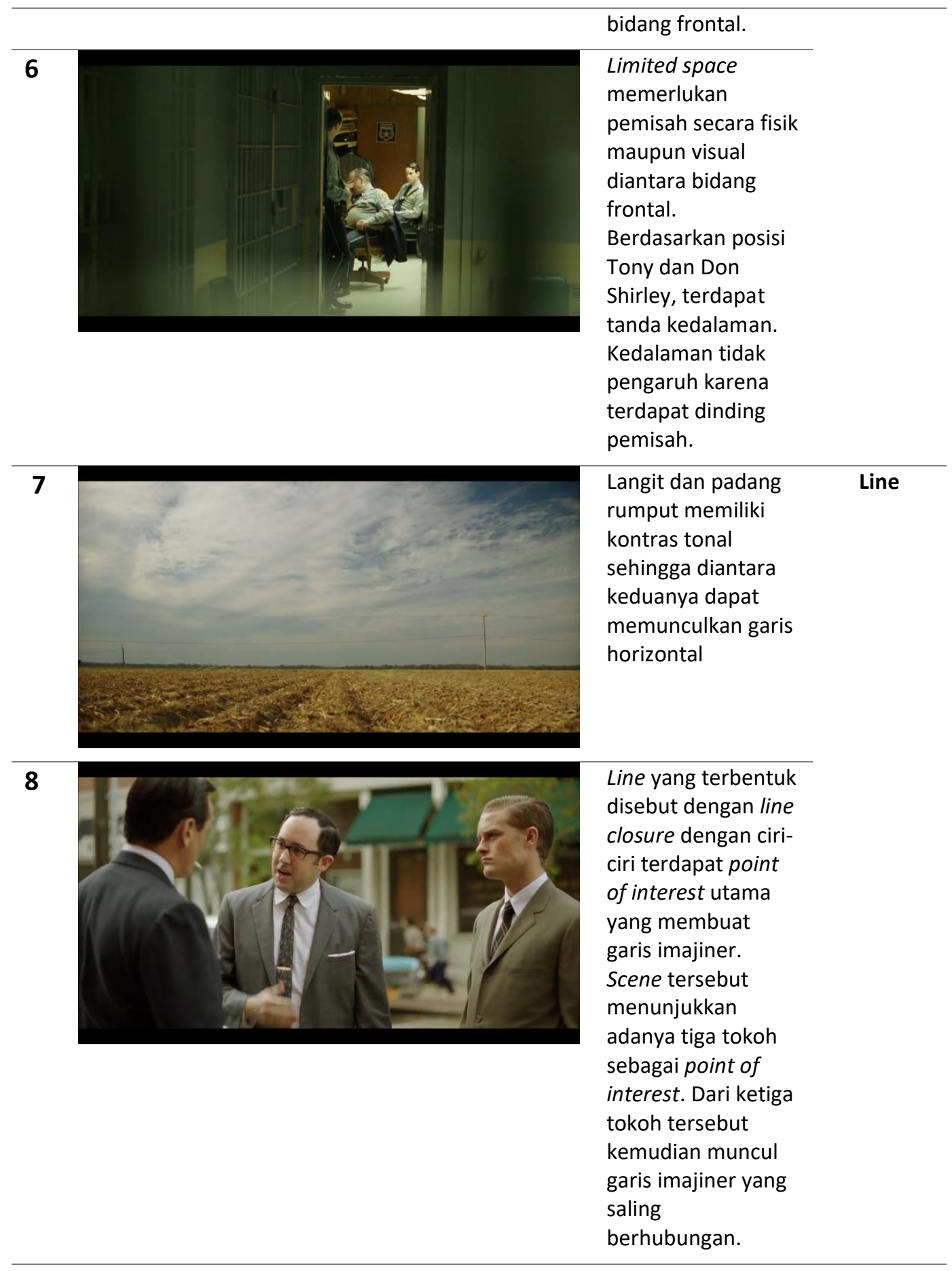




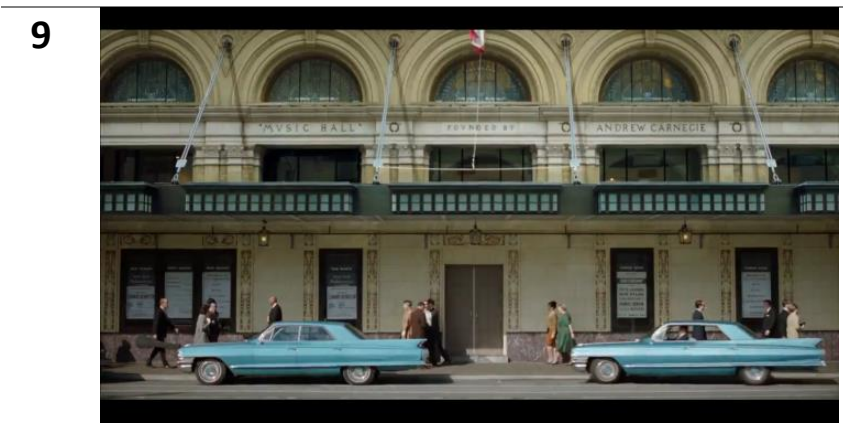

Bentuk dasar yang Shape

paling dominan

adalah kotak/

persegi panjang.

Bentuk tersebut

tampak dari pintu,

jendela maupun

properti bangunan

lainnya. Selain itu

muncul bentuk

dasar seperti

setengah lingkaran

pada jendela atas

bangunan.

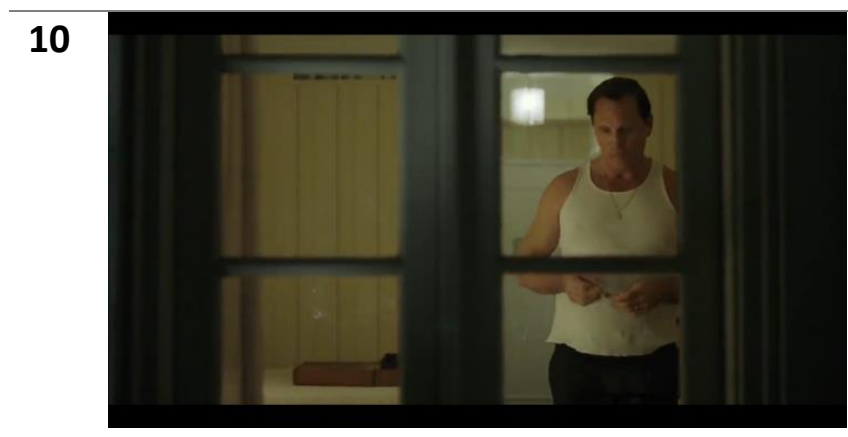

Sudut pengambilan gambar diambil dari sisi luar jendela kamar hotel yang di dalam terlihat Tony Lip. Shape yang muncul berupa bentuk dasar kotak atau persegi.

Bentuk tersebut tampak dari sisi-sisi jendela kaca.

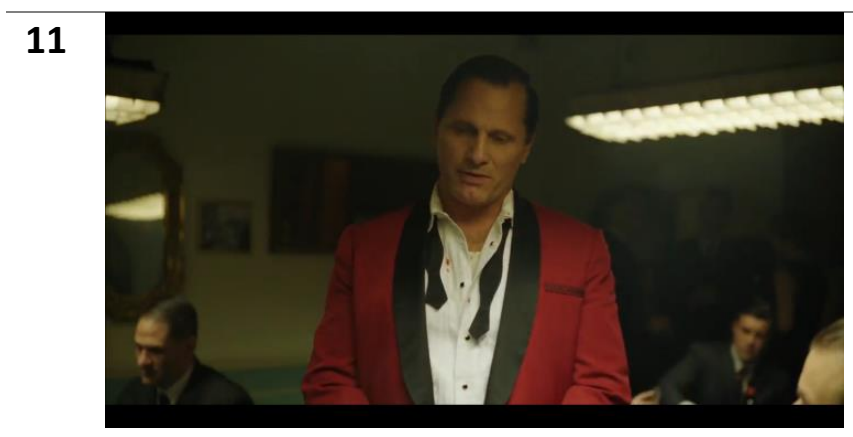

Teknik tonal yang digunakan dalam adegan di atas adalah reflective control. Rentang kecerahan gambar dapat dikontrol oleh nilai pantulan aktual objek.

12

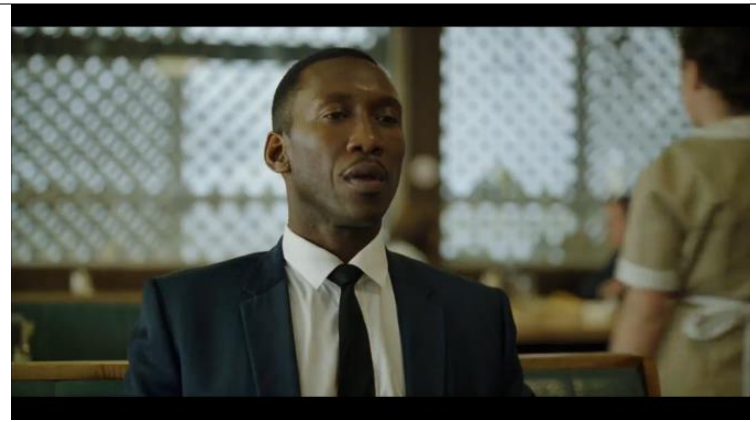

Tone yang muncul coincidence of tone. Lebih menekankan pada pengorganisasian tonal diantara shot dan subyek. Coincidence of tone terjadi ketika tonal menunjukkan atau mengungkapkan obyek. 
13

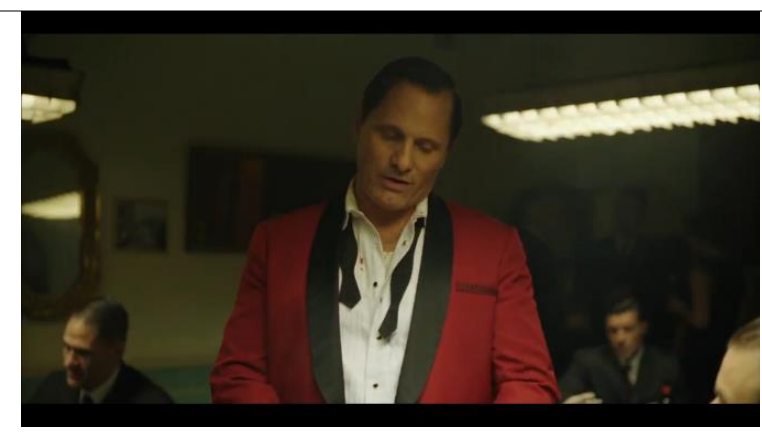

Warna merah

sangat kontras jika

dibandingkan

dengan latar

belakang yang

dipakai pada scene

tersebut. Warna

merah juga

menunjukkan

bahwa seorang

Tony Lip yang

memiliki peran

yang sangat

menonjol dalam

cerita tersebut.

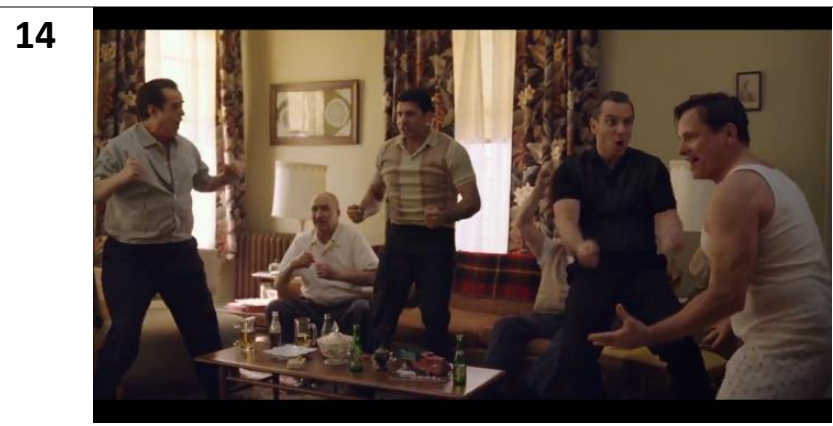

\section{Warna yang}

dominan

monokromatik

kuning. Warna

monokromatik

kuning yang dipakai

juga terlihat lembut

dan teduh. Kuning

dapat digunakan

untuk

memperlihatkan

kehangatan

keluarga Tony Lip.

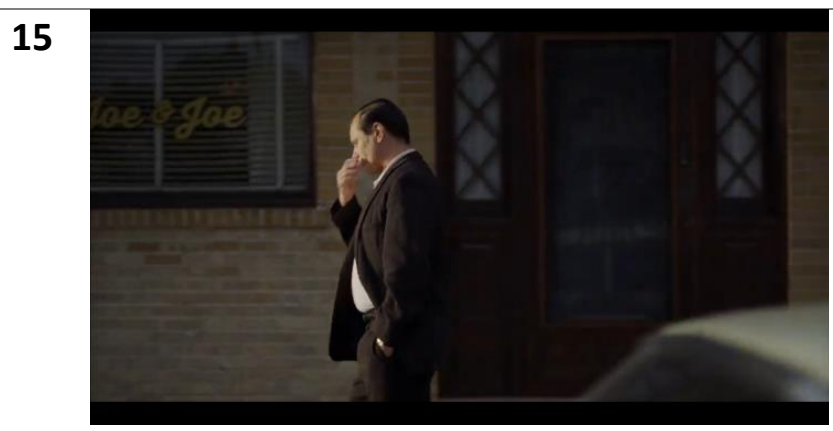

Komponen

Movement

movement dalam

adegan tersebut

terjadi pada obyek

kamera yang

menyorot Tony

sedang berjalan.

Kamera mengikuti

Tony hingga sampai

ke pintu bar yang

dituju. Pergerakan

kamera ini dapat

disebut dengan

tracking shot 


\section{6}

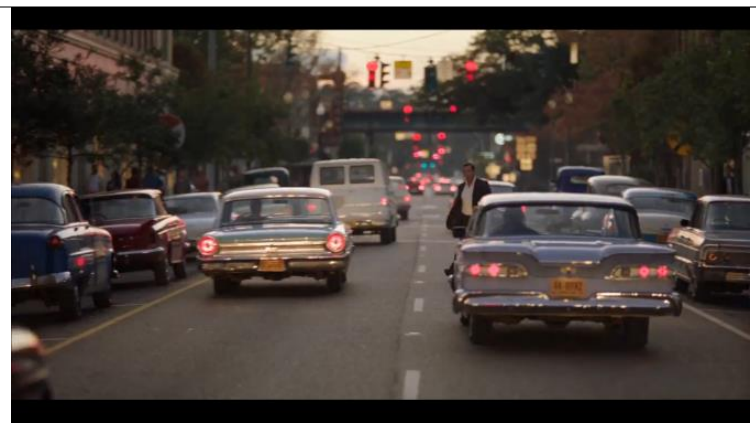

17

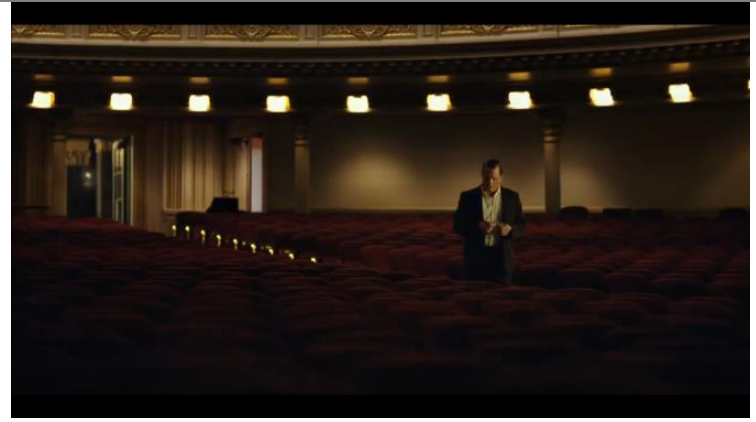

18

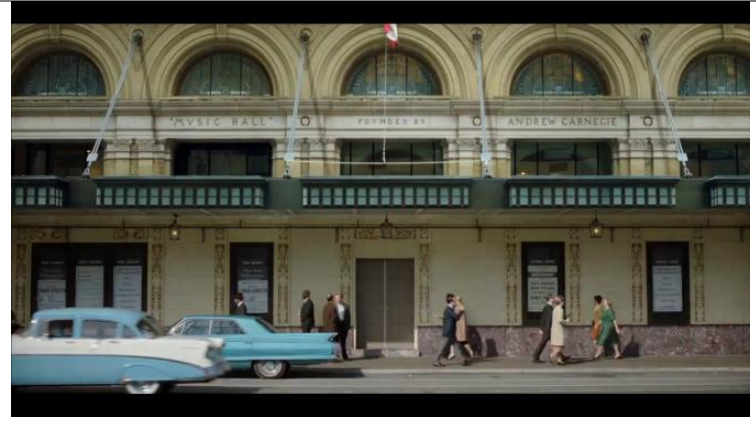

Pergerakan kamera yang terjadi dapat disebut dengan panning. Panning merupakan teknik pengambilan gambar dengan menggerakkan kamera ke kiri atau ke kanan tetapi posisi kamera tetap berada di sumbunya (tidak berubah posisi).

\section{Ritme pada scene} tersebut dapat disebut dengan repetition atau perulangan. Obyek lampu maupun kursi tampak memiliki posisi yang berulang-ulang.
Ritme yang terjadi
pada scene
tersebut adalah
repetition atau
perulangan.
Repetition atau
perulangan terlihat
dari obyek jendela
baik yang
berbentuk setangah
lingkaran maupun
yang berbentuk
persegi.

\section{KESIMPULAN}

Film merupakan salah satu media desain yang memiliki ciri terdiri dari berbagai potongan gambar. Sebagai media desain, film juga memiliki komponenkomponen dasar. Komponen dasar tersebut tertuang dalam teori Bruce Block mengenai basic component visual. Penelitian ini dilakukan untuk menganalisis komponen visual dasar yang terdapat dalam film. Green Book menjadi film yang 
dianalisis karena film ini menjadi film terbaik dan banyak memenangkan penghargaan, salah satunya yang paling bergengsi adalah Best Pictures dalam Academy Award 2019.

Komponen visual dasar dalam film Green Book menunjukkan bahwa film tersebut memiliki komposisi komponen visual yang komplit. Space merupakan komponen visual yang dominan karena hasil analisis menunjukkan adanya deep space, flat space, dan limited space. Line dan shape juga memiliki komposisi yang rapi dalam tiap scene adegan film tersebut. Tone serta color yang digunakan memiliki karakteristik yang lembut dan teduh yang cocok dengan genre film tersebut yaitu drama. Movement dan rhythm memiliki peran dalam menyajikan visualisasi yang tampak rapi dengan penggunaan pergerakan dan ritme yang sederhana tapi tetap memiliki porsi yang cukup. Penelitian ini masih terbatas dalam menganalisis tiap visual adegan pada film Green Book. Tidak semua adegan dapat dianalisis karena berdasarkan durasi, film tersebut memiliki adegan yang sangat banyak. Sehingga masih butuh banyak perbaikan untuk membuat penelitian ini lebih baik lagi; yang mana untuk penelitian lebih lanjut, dapat dilakukan analisis lebih mendalam dengan menggunakan pendekatan semiotik.

\section{DAFTAR PUSTAKA}

Anggraini, E. K. C. D., 2016. Analisa Teknik Sinematografi Pada Film PseudoDokumenter "Paranormal Activity". Jurusan Seni dan Desain. Malang: Universitas Negeri Malang.

Anon., 2019. Wikipedia. [Online] Tersedia di: https://en.wikipedia.org/[Diakses 20 Juni 2019].

Anon, 2019. https://www.imdb.com/. [Online] Tersedia di:

https://www.imdb.com/title/tt6966692/[Diakses 24 July 2019]. 
Block, B., 2008. The Visual Story: Creating The Visual Structure of Film, TV and Digital Media. 2nd ed. Oxford: Elsevier.

Brown, B., 2012. Cinematography Theory And Practice: Image Making for Cinematographers and Directors. 2nd ed. Oxford: Focal Press.

Maulati, D., dan Prasetio, A., 2017. Representasi Peran Ibu Dalam Film "Room". s.I., e-Proceeding of Management.

Effendy, H., 2009. Mari Membuat Film. Kedua ed. Jakarta: Erlangga.

Monica, L. C. L., 2011. Efek Warna Dalam Dunia Desain dan Periklanan. Humaniora, Volume 2, pp. 1084-1096.

Somantri, G. R., 2005. Memahami Metode Kualitatif. Makara Seri Sosial Humaniora, Volume 9, pp. 57-65.

Yuwandi, I., 2018. Analisis Sinematografi dalam Film Polem Ibrahim dan Dilarang Mati di Tanah Ini. Repository UIN Ar Raniry Aceh.

Zoebazary, I., 2010. Kamus Istilah Televisi dan Film. Jakarta: Gramedia Pustaka Utama. 